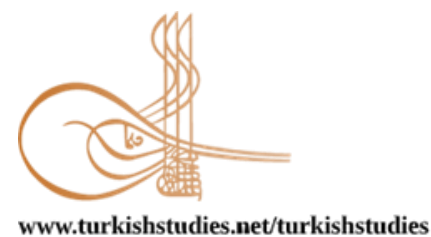

Turkish Studies

\title{
Yeni Tip Koronavirüs (SARS-CoV2) Salgınına Bağlı Uzaktan Eğitim Sürecinin Sınıf Öğretmenlerinin Görüşleriyle Değerlendirilmesi
}

\author{
Evaluation of Distance Education Process Due to New Type of Coronavirus (SARS-CoV2) \\ Pandemic with the Opinions of Elementary School Classroom Teachers
}

\author{
Muhammet Sönmez - Kasım Yıldırım** - Fatih Çetin Çetinkaya***
}

\begin{abstract}
The aim of this study was to evaluate distance education process which is result of new type coronavirus pandemic, through the elementary school classroom teachers' opinions. The present research was a descriptive case study. The sample of the research consisted of 215 elementary school classroom teachers. The research was approved by Düzce University Institute of Social Sciences with the decision number 2020/174 in the ethics committee process. The participants were reached through social media platforms such as Facebook, Instagram, and WhatsApp and volunteer elementary school classroom teachers were asked to contribute to the research. The research data was collected through a questionnaire form created on Google Forms. The questionnaire created consists of 17 items, 5 of which are for determining demographic characteristics of the participants. The experts' opinions were used while creating this questionnaire. The created electronic questionnaire link was sent to the teachers via Facebook, Instagram and WhatsApp. When the responses to the questionnaire stopped, the data collection process of the research was completed. This process took a total of 2 weeks. The data obtained were analyzed by content analysis. The findings of the research were created by analyzing the data obtained. The research findings concluded that distance education carried out during the pandemic was highly affected by the socio-economic situation. The opinions on EBA contents differed according to the type of school where the teachers work and the location of the school. While it was concluded that mothers helped the education of children most during the epidemic process, teachers stated that continuing education despite the epidemic process was one of the strengths of distance education. At the end of the study, suggestions for enriching EBA elementary school contents and future research are included.
\end{abstract}

\footnotetext{
* Öğretmen, MEB

Teacher, Republic of Turkey, Ministry of National Education

ORCID 0000-0001-6516-7635

muhammetsnmz41@gmail.com

*** Prof. Dr., Muğla Sitk1 Koçman Üniversitesi, Eğitim Fakültesi, Temel Eğitim Bölümü

Prof. Dr., Muğla sitki Kocman Üniversity, Faculty of Education, Department of Elementary Education

ORCID 0000-0003-1406-709X

dogukanepsilon@gmail.com

**** Prof. Dr., Düzce Üniversitesi, Eğitim Fakültesi, Temel Eğitim Bölümü

Prof. Dr., Duzce Üniversity, Faculty of Education, Department of Elemantray Education

ORCID 0000-0002-9843-6747

fatihcetincetinkaya@gmail.com

Cite as/ Atıf: Sönmez, M., Yıldırım, K. \& Çetinkaya, F. Ç. (2020). Yeni tip Koronavirüs (SARS-CoV2) salgınına bağlı uzaktan eğitim sürecinin sınıf öğretmenlerinin görüşleriyle değerlendirilmesi. Turkish Studies, 15(6), 855-875. https://dx.doi.org/10.7827/TurkishStudies.43799

Received/Geliş: 27 May/Mayıs 2020

Accepted/Kabul: 15 October/Ekim 2020

Copyright $(\mathrm{C}$ MDE, Turkey

Checked by plagiarism software

Published/Yayın: 20 October/Ekim 2020

CC BY-NC 4.0
} 
Structured Abstract: In the last days of December in 2019, the virus (He, Deng and $\mathrm{Li}, 2020$ ) originated in Wuhan City in China for unknown reasons has named 'coronavirus' [(SARS-CoV-2) (COVID-19)] by the World Health Organization (WHO). (Lu, Zhao, Li, Nui, Yang, Whu and the others... 2020) And again by WHO this virus has announced to the whole entire world that it turned to a pandemic on March 12, 2020. Coronavirus disease which has turned into a pandemichas not only effected human health, it also effected in economic, political, moral and education problems. (Üstün and Özçiftçi, 2020) According to the data of the United Nations, the mass of 770 million students in the world has been affected by the closure of schools and universities due to the coronavirus outbreak. (Zhong, 2020) According to the reports of UNESCO, 1,724,657,870 students have affected in the process until 17 April 2020. (UNESCO, 2020.) Following the detection of the first case of schools have been two week holiday in Turkey, then it was reported to be carried out with an official statement through distance learning education. (Ministry of Education in Turkey) In the coronavirus epidemic process, the distance education process was started by using the Education Information Network (EBA), which is an application affiliated to the Ministry of National Education. Distance education, in its simplest definition, is explained as the educational technology used when the teacher and student are in different environments (Erturgut, 2008). United States Distance Learning Association (USDLA) (2004), describes intertwined technology while expressing distance learning; distance education is to provide education to distant students with the help of multimedia technologies such as computer, audio, video, graphics. In order to realize distance education, a number of components need to come together, educational, pedagogical and technological conditions affect the quality and accessibility of distance education (Özkul \& Girginer, 2001). Education activities are expected to be carried out by teachers again in the epidemic process in various countries and teachers are not given adequate support in this process, it is stated that teachers who have not been given any education for distance education were caught unprepared, at the same time, the socio-economic situation of the school, student age groups and grade levels have a significant impact on the quality of distance education (TEDMEM, 2020).

This study is important as it is one of the first studies carried out during the epidemic as well as evaluating the opinions of the primary school teachers about the distance education process initiated due to the new type of coronavirus epidemic.

\section{Method}

This study, which aims to examine the opinions of primary school teachers about the distance education process initiated due to the epidemic, was a descriptive case study.

The sample of the research consists of 215 classroom teachers. While determining the sample, convenience sampling of sampling methods was used. The questionnaire developed by the researchers was used as a data collection tool. Expert opinions were consulted for the prepared questions. The prepared questions were rearranged with expert opinions and took their final form. It is aimed to collect the data of the research with a questionnaire with a total of 17 questions. After determining the questions to be used for research, a questionnaire form link was created on the internet via Google Forms. This link was shared in the groups including classroom teachers via Facebook, Instagram and WhatsApp applications, and the participants were reached. The answers to the questionnaire form, which is the data collection tool of the research, were subjected to content analysis in the data analysis section. The frequencies and percentages of the answers in the same category were determined and added to the tables. At the same time, excerpts from the participants' opinions are included to support the codings reached.

\section{Findings, Result and Discussion}

According to the results obtained from the findings of the research, television is used mostly to provide access to distance education initiated due to the corona virus outbreak. Primary school teachers find distance learning course contents mostly suitable for their class levels, while the content is insufficient according to the level according to the participants working in the private school. However, the idea that the suitability of the content level decreases as we go from cities to rural areas. It is noteworthy that the views on the limitation of the duration of the lessons are noteworthy, and in addition, the content of the lessons is not sufficient. Mothers mostly support the students during the epidemic. In addition to all these, the socioeconomic situation's accessibility to distance education and the important effects of this education are among the important results of the research. Yamamoto and Altun (2020) report that Covid-19 and distance education will become an alternative in the future and become the basic ground for education. In such a situation, considering the results of this research, it is thought that equal opportunities in education will not 
be utilized unless adequate studies are conducted for the children of families with low socio-economic status. Saavedra (2020), who takes the epidemic process as a basis, states that the poor children will feel the effects of the epidemic on education more, he talks about the learning losses and the possibility of leaving school and also he mentions that disadvantaged children that doesn't have the parents who are interested and supportive to them haven't so much oppurtinty to continue technical or educational activities about the tools such as study desk, book, internet. According to the results of this research, it is seen that socio-economic situation has important effects on access and sustainability of distance education. The working environment of the student, the professions of the family members, the number of siblings, the geographical region they live in and the opportunities provided by the family to the student affect the process. With the aim of advancing distance education more beneficially and supporting the social life of the child as well as supporting the social life, it can be supported by creating an entertainment zone with the exception of the course achievements of the entire primary school level by adding fairy tale expressions, finger games and children's songs. Equipment support can be provided to students who do not have remote access determined by teachers and school administrators. By preparing content for families, information can be given on how to support student education. Contribution can be made to the literature by extensive research on the online education competencies of teachers and academicians.

Keywords: Primary education, SARS-CoV2, Distance learning, Primary school teacher, Socioeconomic status.

Öz: Bu araştırmanın amacı yeni tip koronavirüs salgını nedeniyle başlayan uzaktan eğitim sürecinde yaşananları, salgının eğitime etkilerini sınıf öğretmenlerinin görüşleri doğrultusunda değerlendirmektir. Bu amaç doğrultusunda araştırma betimsel bir durum saptaması niteliğindedir. Araştırmanın çalışma grubunu toplam 215 sınıf öğretmeni oluşturmuştur. Araştırma etik kurul sürecinde 2020/174 sayılı karar ile Düzce Üniversitesi Sosyal Bilimler Enstitüsü tarafından uygulamaya uygun bulunmuştur. Katılımcılara Facebook, Instagram ve WhatsApp gibi sosyal medya platformlarından ulaşılmış ve gönüllü olan sınıf öğretmenlerinin araştırmaya katkı sağlaması istenmiştir. Araştırma verileri Google Formlar üzerinden oluşturulan anket formuyla toplanmıştır. Oluşturulan anket formu 5 tanesi demografik özellikleri belirlemeye yönelik toplamda 17 sorudan oluşmaktadır. Bu anket formu oluşturulurken uzman görüşlerinden yararlanılmıştır. Oluşturulan elektronik anket formu bağlantı linki Facebook, Instagram ve WhatsApp üzerinden sınıf öğretmenlerine gönderilmiştir. Anket formuna gelen yanıtlar durduğunda araştırmanın veri toplama süreci tamamlanmıştır. Bu süreç toplam 2 hafta sürmüştür. Elde edilen veriler içerik analizii ile çözümlenmiştir. Elde edilen verilerin analiziyle araştırmanın bulguları oluşturulmuştur. Sınıf öğretmenlerinin görüşleriyle gerçekleştirilen çalışmada salgın sürecinde gerçekleştirilen uzaktan eğitimin sosyo-ekonomik durumdan yüksek ölçüde etkilendiği sonucuna ulaşılmıştır. EBA içeriklerine yönelik görüşler ise öğretmenlerin görev yaptıkları okul türü ve okulun konumuna göre farklılık göstermiştir. Salgın sürecinde çocukların eğitimine en çok annelerinin yardımcı olduğu sonucuna ulaşılırken, öğretmenler salgın sürecine rağmen eğitimin devam etmesini uzaktan eğitimin güçlü yönlerinden biri olarak belirtmiştirler. Araştırmanın sonunda EBA ilkokul içeriklerini zenginleştirmeye ve gelecekte yapılabilecek araştırmalara yönelik önerilere yer verilmiştir.

Anahtar Kelimeler: Sınıf eğitimi, Koronavirüs, Uzaktan eğitim, Sınıf öğretmeni, Sosyoekonomik durum.

\section{Giriş}

2019 yılı Aralık ayının son günlerinde Çin'in Wuhan kentinde bilinmeyen nedenlerle ortaya çıkan virüs (He, Deng ve Li, 2020), Dünya Sağlık Örgütü tarafından koronavirüs [(SARSCoV-2) (COVID-19)] olarak adlandırılmış (Lu, Zhao, Li, Nui, Yang, Whu ve diğerleri, 2020) ve yine Dünya Sağlık Örgütü tarafından 12 Mart 2020 tarihinde bu virüsün bir salgına (pandemiye) dönüştüğü tüm dünyaya duyurulmuştur. Küresel bir salgına dönüşen koranavirüs hastalığı insan sağlını etkilemesinin yanı sıra ekonomik, politik, ahlaki ve eğitimsel birçok sorunun da ortaya çıkmasına sebebiyet vermiştir (Üstün ve Özçiftçi, 2020). Özellikle Birleşmiş Milletler tarafindan 17 Nisan 2020 tarihli yayınlanan raporda ortaya çıkan salgın sebebi ile dünya genelinde 191 ülkenin okullarda eğitime devam etmediği ve bu şekilde salgının yayılmasını engellemeye çalıştıkları ifade edilmiştir (Viner ve diğerleri, 2020). Hızla yayılan salgıın Türkiye'de de okulların 
kapanmasına ve beraberinde ilişkili birçok problemin ortaya çıkmasına neden olmuştur. Eğitim sürecinin dijital ortamda asenkron veya senkron uygulamalarla uzaktan sürdürülmesi kararı, uzaktan eğitim sürecinde öğretmen yeterliliklerinin durumunu, sınavların nasıl gerçekleştirileceğini ve öğrenmenin nasıl olacağı vb. eğitimle alakalı birçok değişkenin sorgulanmasına neden olmuştur. $\mathrm{Bu}$ araştırmada koronavirüs salgınına bağlı olarak gelişen uzaktan eğitim sürecinin sınıf öğretmenlerinin görüşleriyle değerlendirilmesi amaçlanmıştır.

İnsan sağlığı koronavirüs hastalığından önemli ölçüde etkilenmiştir. Dünya Sağlık Örgütü (WHO) tarafindan yapılan açıklamada 3 Mart 2020 tarihi itibariyle tahmini ölüm oranının \%3,4 olduğu belirtilmiştir. Hastalığın insan sağlığına etkisinin yanı sıra ekonomiyi de etkilediği görülmüştür (Üstün ve Özçiftçi, 2020). Ekonomi sektörünün belirli yapılarında iflaslar yaşanmakta, seyahat yasakları ve karantina önlemleri sebebiyle birçok insan işlerine gidememektedir (Üstün ve Özçiftçi, 2020). Salgın nedeniyle üretimde yaşanacak azalma ve insanların içine düştügü kaygıların etkisiyle artması beklenen tüketimin, ekonomik verilerde düşüş yaşanması endişesini ortaya çıkarmıştır (Baldwin ve Weder di Mauro, 2020). The Organisation for Economic Co-operation and Development (OECD) tarafından yapılan ilk tahminlere göre korona virüs salgını nedeniyle ülke ekonomilerinin önemli ölçüde etkileneceği belirtilmiştir (OECD, 2020). Türkiye'de de yapılan kısa dönemli ekonomik hesaplamaların ekonominin \%20 yavaşlayacağını öngördüğü aktarılmaktadır (Demir, 2020). Sağlık ve ekonominin yanı sıra koronavirüs salgınından etkilenen bir diğer önemli alan ise eğitimsel faaliyetlerdir.

Birleşmiş Milletler'in verilerine göre dünyadaki 770 milyon kişilik öğrenim gören kitle koronavirüs salgını nedeniyle okul ve üniversitelerin kapanmasından etkilenmiştir (Zhong, 2020). United Nations Educational, Scientific and Cultural Organization (UNESCO) raporlarına göre ise 17 Nisan 2020 gününe kadar olan süreçte, 1.724.657.870 öğrenci virüs nedeniyle yaşanan gelişmelerden etkilendiğini belirtilmiştir (UNESCO, 2020). Virüsün etkisinin bu denli büyük olması nedeniyle birçok ülkede okullar kapatılmıştır. Türkiye'de ilk vakanın tespitinin ardından okullar iki hafta tatil edilmiş, ardından yapılan resmi açıklamalarla eğitimin uzaktan eğitim yoluyla gerçekleştirileceği bildirilmiştir (Milli Eğitim Bakanlığg [MEB], 2020).

Koronavirüs salgını sürecinde ülkemizde MEB bünyesine bağlı bir uygulama olan Eğitim Bilişim Ağını (EBA) kullanılarak uzaktan eğitim sürecine başlanmıştır. EBA web sitesi ilk olarak 2012 yılında test sürümüyle kullanıma açılmıştır (Pala, Arslan ve Özdinç, 2017). EBA herkes tarafından erişilebilir olan, ücretsiz, güvenilir bir uygulamadır, aynı zamanda öğretmen ve öğrenciler tarafından yeni paylaşımlar yapmaya imkân tanıyan çevrimiçi bir eğitim platformudur (EBA, 2017). Öğretmen ve öğrenciler başta olmak üzere eğitim içinde yer alan tüm paydaşların kullanabilmesi için tasarlanan EBA; çeşitli içeriklerle öğretimi zenginleştirebilmekte, bilişim kültürünü eğitime yansıtmakta, zengin ve sürekli gelişen arşiviyle derslere katkı sağlamakta, bütün öğretmenleri ortak bir noktada buluşturarak eğitime yön vermeye destek olmaktadır, tüm bunlara ek olarak teknolojinin bir eğitim aracı olarak kullanılmasına katkı sağlamaktadır (MEB, 2015). Tüm Türkiye'de uzaktan eğitim başlangıcıyla birlikte EBA uygulamaları genişletilerek ulusal Televizyon kanallarında da EBA dersleri yayınlanmaktadır.

Uzaktan eğitim en basit tanımıyla öğretmen ve öğrencinin farklı ortamlarda bulunması durumunda kullanılan eğitim teknolojisi olarak açıklanmaktadır (Erturgut, 2008). Geleneksel eğitim-öğretim yöntemlerinin bir takım sınırlılıkları nedeniyle okul ve sınıf ortamında etkinliklerin yürütülemediği anlarda, farklı iletişim ve etkileşim yöntemlerinden yararlanılarak gerekli bilgi ve beceriler öğrencilere uzaktan eğitim yardımıyla aktarılır (Çağıltay, 2002). Başka bir ifade ile uzaktan eğitim, isteyen herkese istediği yer, zaman ve mekân içersinde her yaş seviyesinde öğrenme imkânı tanımaktır (Adıyaman, 2002).

United States Distance Learning Association (USDLA) (2004) uzaktan eğitimi ifade ederken teknolojiyle iç içe olmasına vurgu yapmaktadır; uzaktan eğitim bilgisayar, ses, video, grafik gibi çoklu ortam teknolojilerinin yardımıyla eğitimin uzaktaki öğrencilere ulaşmasını 
sağlamaktır. Uzaktan eğitimin nitelikli gerçekleştirilebilmesi için bir takım bileşenin bir araya gelmesi gerekmektedir, eğitimsel, pedagojik ve teknolojik şartlar uzaktan eğitimin niteliğini ve ulaşılabilirliğini etkilemektedir (Özkul ve Girginer, 2001). Uzaklığın eğitim almaya engel olduğu durumlarda, belirli bir hastalığa sahip olmak ya da fiziksel engel nedeniyle ev ortamına bağımlı kalma gibi nedenlerle uzaktan eğitim uygulanmaktadır (Newby, Stepich, Lehman ve Russell, 2006). Uzaklık yaş, zaman, fiziksel engelli olma, sosyo-ekonomik durum gibi özellikler uzaktan eğitimi sürekli gündemde tutmaktadır (Adıyaman, 2002).

Ailelerin bu teknolojik alt yapıya ne kadar eriştikleri ve çocuklarına ne kadar destek olabildikleri uzaktan eğitim sürecini önemli ölçüde etkilemektedir. Ailenin soyoekonomik düzeyi, eğitim sürecine ek materyallerle sağladıkları destek, bulundukları coğrafi bölgenin özellikleri ve öğrenci ihtiyaçlarına gösterdikleri ilgi öğrenci akademik başarısı üzerinde etkilidir (Çiftçi ve Çağlar, 2014). Aileler okula yönelik daha fazla materyal sağlayarak ve öğretim faaliyetlerine ağırlık vererek çocukların gelişimlerine katkı sağlayabilmektedir (Baker, Goesling ve Letendre, 2002; Chiu ve Khoo, 2005; Chiu ve Xihua, 2008; Lee ve Barro, 1997; OECD, 2013; Teachman, 1987). Özellikle ilkokul kademesinde okuma, yazma gibi temel becerilerin öğretiminde ailelerin öğrencilere ne kadar destek olabileceği önemlidir. Bu sorun kırsal kesimde yaşayan çeşitli konularda dezavantajlı durumda olan ailelerin çocukları için daha net bir şekilde ortaya çıkmaktadır (TEDMEM, 2020).

Çeşitli ülkelerde salgın sürecinde eğitim faaliyetlerinin yine öğretmenler tarafından yürütülmesi beklenmekte ve öğretmenlere bu süreçte yeterli destek verilmemektedir, daha önce uzaktan eğitime yönelik herhangi bir eğitim verilmeyen öğretmenlerin bu sürece hazırlıksız yakalandığı belirtilmektedir, aynı zamanda öğretmenler yeterli olsa bile okulun içinde bulunduğu sosyo-ekonomik durumu, öğrenci yaş grupları ve sınıf seviyeleri uzaktan eğitimin niteliğine önemli etki yapmaktadır (TEDMEM, 2020).

Alanyazın incelendiğinde uzaktan eğitim çalışmalarının varlı̆̆ 1 (Adıyaman, 2002; Al ve Madran, 2004; Ateş ve Altun, 2008; Aydemir, Küçük ve Karaman, 2012; Birişçi, 2013; Bozkurt, 2017; Demir, 2014; Ekici, 2003; Erturgut, 2008; Kırık, 2014; Odabaş, 2003; Oran ve Karadeniz, 2007; Orhan ve Akkoyunlu, 1999; Yalman, 2013; Yamamoto ve Altun, 2020) görülmektedir. Aynı zamanda sosyo-ekonomik durumun eğitime olan etkisi üzerine yapılmış çalışmalar da bulunmaktadır (Astone ve McLanahan, 1991; Baeck, 2010; Çiftçi ve Çağlar, 2014; Gelbal, 2008; Heyns ve Catsambis, 1986; Kazu, 2019; Kılıç ve Haşıloğlu, 2017; Kurt ve Taş, 2019; Lee ve Bowen, 2006; Lueptow, 1975; Milne, Myers, Reay, 2004; Sui-Chu ve Willms, 1996; Vellymalay, 2012; Yavuz, Odabaş ve Özdemir, 2016; Yolsal, 2016). Ancak yeni tip koronovirüs salgını bağlamında tüm dünyada olduğu gibi Türkiye'de de eğitim faaliyetlerinin durdurulması ve başlatılan uzaktan eğitim süreçlerine yönelik bilimsel çalışmaların (Bayburtlu, 2020; Duban ve Şen, 2020; Karahan, Bozan ve Akçay, 2020; Sirem ve Baş, 2020) çok da fazla olmadığı anlaşılmaktadır. Bu çalışma sınıf öğretmenlerinin yeni tip koronavirüs salgını nedeniyle başlatılan uzaktan eğitim sürecine yönelik görüşlerini değerlendirmesinin yanında salgın sürecinde yapılan ilk çalışmalardan birisi olması dolayısı ile de önem taşımaktadır. Bu araştırmanın amacı yeni tip koronavirüs salgını nedeniyle başlayan uzaktan eğitim sürecinde sınıf öğretmenlerinin salgın sürecinde gerçekleşen uzaktan eğitime yönelik görüşlerini, yaşadıkları zorlukları, öğrencilerine ulaşabilme durumlarını, salgının eğitime etkilerini sınıf öğretmenlerinin görüşleri doğrultusunda değerlendirmektir. Bu genel amaç doğrultusunda aşağıdaki sorulara cevaplar aranmıştır:

1. Salgın sürecinde gerçekleştirilen uzaktan eğitimin sınıf öğretmenlerine göre olumlu ve olmsuz yönleri nelerdir? nelerdir?

2. Salgın sürecinde kullanılan EBA içeriklerine yönelik sınıf öğretmenlerinin görüşleri 
3. Salgının sürecinde gerçekleştirilen uzaktan eğitime yönelik sınıf öğretmeni görüşleri görev yaptıkları okul türüne göre farklılaşıyor mu?

4. Salgının sürecinde gerçekleştirilen uzaktan eğitme yönelik sınıf öğretmeni görüşleri görev yaptıkları okul konumuna göre farklılaşıyor mu?

\section{Yöntem}

\section{Araştırmanın Modeli}

Sınıf öğretmenlerinin salgın nedeniyle başlatılan uzaktan eğitim sürecine yönelik görüşlerini incelemeyi amaçlayan bu çalışma betimsel bir durum saptaması niteliğindedir. Uzaktan eğitim sürecinde öğretmenlerin deneyimlerini belirlemek amacı ile bu yöntemin seçilmesine karar verilmiştir. Aynı zamanda bu yöntem özgün bir bağlamdan daha kapsamlı veri sunulmasına katkı sağlamamaktadır.

\section{Çalışma Grubu}

Araştırmanın çalışma grubu 215 sınıf öğretmeninden oluşmaktadır. Araştırma süreci pandemiden kaynklı olarak ortaya çıkan karantina süreçlerinden gerçekleştirildiğinden kolay ulaşılabilir örneklem yönteminin seçilmesine karar verilmiştir. Bu doğrultuda oluşturulan anket formu elektronik ortamda hazırlanarak sosyal medya hesapları aracılığ ile araştırmaya katılmaya istekli ve gönnülü sınıf öğretmenlerine ulaştırılmıştır. Bu da araştırmacıların bu zor şartlar altında araştırmayı gerçekleştirebilmelerine olanak sağlamıştır. Bundan dolayı araştırmada kolay ulaşılabilir örneklem yöntemi tercih edilmiştir. $\mathrm{Bu}$ örnekleme yöntemine göre araştırmacılar ulaş1lması daha kolay ve pratik olan örneklemleri tercih etmektedir (Glesne, 2015; Patton, 2002). Çalışma grubundaki katılımcıların demografik özelliklerine yönelik bilgiler aşağıdaki tablolarda sunulmuştur.

Tablo 1: Çalışmaya Katılan Sınıf Öğretmenlerinin Mesleki Kıdemleri

\begin{tabular}{|c|c|c|}
\hline & Kidem Y1l1 & Öğretmen Say1 \\
\hline \multirow{4}{*}{$\begin{array}{l}\text { Çalışmaya katılan sınıf } \\
\text { ögretmenlerinin mesleki } \\
\text { kıdemleri }\end{array}$} & $1-5$ Yil & 101 \\
\hline & 6-10 Yil & 36 \\
\hline & 11-15 Y1l & 28 \\
\hline & 16 ve 16 Y1ldan fazla & 50 \\
\hline
\end{tabular}

Çalışmaya katılan sınıf öğretmenlerinin 101 tanesi 1 ile 5 yıl arasında öğretmenlik yapmaktadır. 36 öğretmen 6 ile 10 y1l, 28 öğretmen 11-15 yıl ve 50 öğretmen ise 16 yıl ve 16 yıldan fazla kıdeme sahiptir.

Tablo 2: Çalışmaya Katılan Sınıf Öğretmenlerinin Çalışma Esnasında Okuttukları Sınıf Seviyeleri

\begin{tabular}{|c|c|c|}
\hline & Sinıf seviyesi & Öğretmen Sayı \\
\hline Çalışmaya & 1. $\sin i f$ & 69 \\
\hline öğretmenlerinin & 2. $\sin 1 f$ & 47 \\
\hline esnasında okuttukları sinıf & 3. sinif & 47 \\
\hline seviyeleri & 4. sinif & 52 \\
\hline
\end{tabular}

Sınıf öğretmenlerinin araştırma esnasında okuttukları sınıf seviyeleri yoğun olarak 1. sinıftır. 1. Sınıf okutan katılımcı sayıs1 69, 2. Sınıf ve 3. Sınıf okutan sınıf öğretmeni sayısı 47 ve son olarak 4. Sinıf okutan katılımcı sayıs1 52dir.

Tablo 3: Çalışmaya Katılan Sınıf Öğretmenlerinin Görev Yaptıkları Okul Türü

\begin{tabular}{ccc}
\hline & Okul Türü & Öğretmen Sayı \\
\hline Çalışmaya katılan sınıf & Devlet okulu & 196 \\
öğretmenlerinin görev & Özel okul & 19 \\
yaptıkları okul türü & & \\
\hline
\end{tabular}


Çalışmaya katılan toplam 215 katılımcıdan 196 tanesi devlet okulunda görev yaparken 19 katılımcı özel okulda görev yapmaktadır.

Tablo 4: Çalışmaya Katılan Sınıf Öğretmenlerinin Görev Yaptıkları Okulun Konumu

\begin{tabular}{lccc}
\hline & & Okul konumu & Öğretmen Sayı \\
\hline Çalış̧maya katılan & sınıf & Şehir merkezi & 91 \\
öğretmenlerinin & görev & İlçe & 94 \\
yaptıkları okul türü & & Köy & 30 \\
\hline
\end{tabular}

Katılımcıların 91 tanesi şehir merkezinde bulunan bir okulda görev yapmakta, 94 katılımcı ilçede bulunan bir okulda görev yapmakta ve son olarak 30 katılımcı köy okulunda görev yapmaktadir.

\section{Veri Toplama Araçları}

Araştırmacılardan tarafından geliştirilen anket formu veri toplama aracı olarak kullanılmıştır. Hazırlanan sorular için lisansüstü eğitim almış 4 sınıf öğretmeni ve sınıf eğitimi üzerine uzmanlaşmış 2 akademisyenin görüşlerine başvurulmuştur. Hazırlanan sorular uzman görüşleriyle tekrar düzenlenmiş ve son şeklini almıştır. Toplam 17 soruluk bir anket formu ile araştırmanın verilerinin toplanması hedeflenmiştir. Soruların 5 tanesi demografik bilgileri ölçmeyi hedeflemektedir. 12 soru ise açık uçlu soru formatındadır. İlgili anket formu araştırmanın ekler kısmında yer almaktadır.

\section{Verilerin Toplanması}

Araştırma için kullanılacak soruların belirlenmesinin ardından Google Formlar aracılığıyla internet ortamında bir anket formu linki oluşturulmuştur. Araştırma için gerekli etik kurul izni 2020/174 sayıl1 karar ile Düzce Üniversitesi Sosyal Bilimler Enstitüsü tarafindan verilmiştir. Akabinde oluşturulan link Facebook, Instagram ve WhatsApp uygulamaları üzerinden sinıf öğretmenlerinin dâhil olduğu gruplarda paylaşılarak katılımcılara ulaşılmıştır. Anket, sınıf öğretmenleriyle paylaşılırken katılımın tamamen gönüllülük esaslı olduğu belirtilmiş, katılımcılardan sorulara içten ve samimi bir şekilde cevap vermeleri istenmiştir. Anket formun hazırlanması paylaşılması ve cevapların alınması 2 haftalık süreçte tamamlanmıştır. Anket formuna gelen yanıtlar durduğunda veri toplama aşaması bitirilip elde edilen veriler analiz edilerek araştırmanın bulguları haline getirilmiştir.

\section{Verilerin Analizi}

Verilerin analizi kısmında araştırmanın veri toplama aracı olan anket formuna gelen yanıtlar içerik analizine tabi tutulmuştur. Araştırma verileri analiz edilmeden önce Google Formlar üzerinden alınan yanıtlar soru başlıkları üzerinde değerlendirilerek Excel ortamına aktarılmıştır. Excel ortamında benzer yanıtlar kategorileştirilmiştir. Aynı kategoride gelen cevapların sıklıkları ve yüzdeleri belirlenerek tablolara eklenmiştir. Aynı zamanda ulaşılan kodlamaları desteklemek için katılımcıların görüşlerinden örnek alıntılara yer verilmiştir.

Araştırmada elde edilen verilerin kodlamaları iki araştırmacı tarafından gerçekleştirilmiştir. Yapılan içerik analizi ve ulaşılan kodlamalar arasındaki tutarlılık güvenirliliği Miles ve Huberman (1994) tarafından geliştirilen formüle göre hesaplanmıştır. Miles ve Huberman modelinde içsel tutarlılık olarak adlandırılan ve kodlayıcılar arasındaki görüş birliği olarak kavramsallaştırılan bu benzerlik: $\Delta=C \div(\mathrm{C}+\square) \times 100$ formülü kullanılarak hesaplanabilir. Formülde, $\Delta$ : Güvenirlik katsayısını, C : Üzerinde görüş birliği sağlanan konu/terim sayısını, $\partial$ : Üzerinde görüş birliği bulunmayan konu/terim sayısını ifade etmektedir. İçsel tutarlılığı veren kodlama denetimine göre kodlayıcılar arası görüş birliğinin en az \% 80 olması beklenmektedir (Miles ve Huberman, 1994). $\mathrm{Bu}$ araştırmada da kodlayıcılar arasında tutarlılık \%87 olarak elde edilmiştir. 


\section{Bulgular}

Araştırma sürecinde katılımcılara uygulanan formlar içerik analizi yöntemiyle incelenmiş ve tablolar haline getirilerek araştırmanın bulguları ortaya konulmuştur. Araştırmanın bulguları şu şekildedir;

Tablo 5: Katılımcılar Öğrencilerinin Çoğunluğunun EBA Derslerini Takip Edebilmek İçin Kullandıkları Araçlara Yönelik Görüşleri

\begin{tabular}{lcc}
\hline & & Kullanılan araçlar \\
\hline En çok kullanılan & 1. Televizyon \\
araçlar. & 2. Telefon \\
\hline
\end{tabular}

Tablo 5 incelendiğinde katılımcılar, EBA derslerinin takip edilmesinde en çok Televizyonun kullanıldığını belirtmiştir. Televizyonun yanı sıra telefon ve bilgisayar da yoğun olarak kullanılan araçlardandır.

Tablo 6: Katılımcılar Tarafindan EBA İçeriklerinin Kendi Sınıf Seviyelerine Uygun Bulunma Durumu

\begin{tabular}{llcc}
\hline & $f$ & $\%$ \\
\hline Evet uygun & 153 & 71.16 \\
Hayır, uygun değil & 62 & 28.84 \\
Toplam & 215 & 100.00 \\
\hline
\end{tabular}

Tablo 6 da katılımcıların EBA içeriklerinin kendi sınıf seviyelerine uygunluğu ile ilgili görüşleri yer almaktadır. Bu görüşlere göre katılımcıların 153'ü yani \%71.16'sı içeriklerin kendi sınıf seviyelerine uygun olduğunu aktarmaktadır. 62 katılımc1 ise sınıf seviyelerine uygun bulmadığını belirtmiştir. Genel olarak uygun bulmama sebeplerine bakıldığında EBA içeriklerinin bireysel farklılıklara hitap edemeyeceği seviyenin üstün de ya da altında konu anlatımları ön plana çıkmaktadır. Örneğin;

K156: 2.sinıf olarak içeriğin yetersiz olduğunu düşünüyorum. Örnek olarak Matematik dersi bölme işlemi konu anlatımında üst sınıfların kazanımlarına yönelik anlatımlar var.

K32: Seviye olarak ögrencilerimin seviyelerine göre daha basit içerikler ile ilerlediğini gözlemlemekteyim. Süreçte ögrencilerimden ricam takip etmememiz noktasında eksiklik yaşamak istemememdi. Öğrencilerim aktif olarak takip ediyorlar. Öğrencilerim ile birlikte süreç içinde değerlendirmeler yapmaktayı.

K177: EBA TV'deki İngilizce ögretmeni çok başarılı ama çocuklar EBA derslerindeki Ingilizceyi anlayacak kadar hâkim değiller.

Tablo 7: Katılımcıların EBA İçeriklerini Kendi Sınıf Seviyelerine Uygun Bulmama Nedenleri

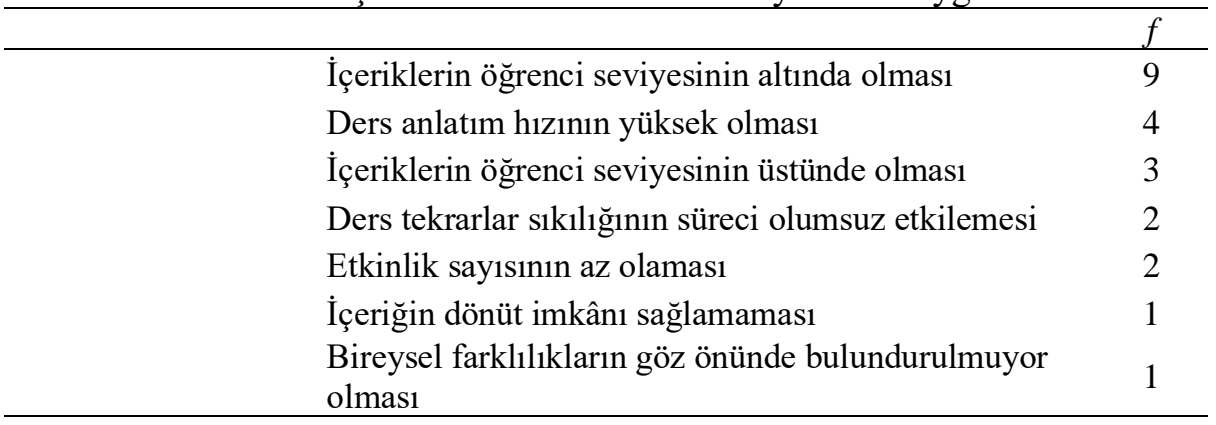

Katılımcıların içerikleri uygun bulmama nedenleri incelendiğinde içeriğin kendi sınıf seviylerinin altında veya üstünde olması, anlatım hızının yüksekliği, içerik tekrarları, etkinlik 
sayısındaki yetersizlik, etkin dönüt sağlanamaması ve bireysel farklılıklara hitap etmemesi şeklinde olduğu görülmektedir.

Tablo 8: Katılımcılar Tarafından EBA İçeriklerinin Okul Türüne Göre Kendi Sınıf Seviyelerine

\begin{tabular}{llcc}
\multicolumn{3}{c}{ Uygun Bulunma Durumu } & \\
\hline \multirow{3}{*}{ Devlet okulu } & Evet uygun & $f$ & $\%$ \\
& Hayır, uygun değil & 144 & 73.47 \\
& Toplam & 52 & 26.53 \\
& Evet uygun & 196 & 100 \\
\hline \multirow{3}{*}{ Özel okulu } & Hayır, uygun değil & 9 & 47.37 \\
& Toplam & 10 & 52.63 \\
& & 19 & 100 \\
\hline
\end{tabular}

Tablo 8'e bakıldığında devlet okulunda görev yapan toplam katılımcı sayısının 196 olduğu görülmektedir. Katılımcıların 144 tanesi yani toplam katılımcı sayısının \%73.47'si EBA içeriklerini kendi sınıf seviyelerine uygun bulmaktadır. Özel okulda görev yapan katılımcıların \%47.37 si EBA içeriklerini kendi sınıf seviyelerine uygun olduğunu aktarmıştır. Bu bağlamda devlet okullarında çoğunluk EBA içeriklerini sınıf seviyelerine uygun bulurken özel okullarda çoğunluk uygun bulmadığını ifade etmiştir. Devlet okulları katılımcıları uygun bulmama nedenlerini kendi sinıf seviyelerine göre EBA içerik seviyesinin yüksek olduğunu ifade ederken özel okul katılımcıları seviyenin yükseltilmesi gerektiğini ifade etmiştir.

K32 (Özel okul): Seviye olarak öğrencilerimin seviyelerine göre daha basit içerikler ile ilerlediğini gözlemlemekteyim. Süreçte öğrencilerimden ricam takip etmememiz noktasında eksiklik yaşamak istemememdi. Öğrencilerim aktif olarak takip ediyorlar. Öğrencilerim ile birlikte süreç içinde değerlendirmeler yapmaktayız.

K177 (Devlet Okulu): EBA TV'deki İngilizce öğretmeni çok başarılı ama çocuklar EBA derslerindeki İngilizceyi anlayacak kadar hâkim değiller.

Tablo 9: Katılımcılar Tarafından EBA İçeriklerinin Okul Konumuna Göre Kendi Sınıf Seviyelerine Uygun Bulunma Durumu

\begin{tabular}{llcc}
\multicolumn{2}{c}{ Seviyelerine Uygun Bulunma Durumu } & & \\
\hline & & $f$ & $\%$ \\
\hline \multirow{3}{*}{ Şehir merkezi } & Evet uygun & 70 & 76.92 \\
& Hayır, uygun değil & 21 & 23.08 \\
& Toplam & 91 & 100 \\
\hline \multirow{3}{*}{ İlçe merkezi } & Evet uygun & 69 & 73.40 \\
& Hayır, uygun değil & 25 & 26.60 \\
& Toplam & 94 & 100 \\
\hline \multirow{3}{*}{ Köy merkezi } & Evet uygun & 15 & 50.00 \\
& Hayır, uygun değil & 15 & 50.00 \\
& Toplam & 30 & 100 \\
\hline
\end{tabular}

Tablo 9'a bakıldığında okul konularına göre EBA içeriklerinin katılımcılarının sınıf seviyelerine uygunluğu görülmektedir. Tabloya göre şehir merkezinde görev yapan katılımcıların \%76.92'si uygunluğunu ifade etmiş, ilçede görev yapanların \%73.40 ve köyde görev yapan katılımcıların ise \%50'si uygun olduğunu belirtmiştir. Şehir merkezinden köye doğru gidildikçe uygun bulma yüzdesinde düşüş yaşandığı görülmektedir. ) Uygun bulmayan katılımc1 görüşlerine bakıldığında şehir ve ilçe merkezinde görev yapan katılımciların içeriklerin öğrenci seviyelerine göre kolay kaldığını ve yayın hızının yüksek olduğunu belirttiği ortaya çıkmaktadır. Köyde görev yapan katılımcılar ise sınıf seviyelerinin EBA içeriklerine göre yetersiz olduğunu aktarmaktadır. 
K136 (Şehir Merkezi): Hayır, içerik basit kalıyor

K48 (Şehir Merkezi): Kesinlikle düşünmüyorum. Yayınlar çok hızlı ilerliyor. Öğrencilerin anlaması ve kavraması çok zor bence.

K167 (Illçe Merkezi): Benim öğrencilerimin seviyesinin altında kalıyor

K18 (Illçe Merkezi): Eba da konular hızlı işleniyor.

K46 (Köy Merkezi): Tüm öğrencilerin seviyelerine uygun değil.

Tablo 10: Katılımcıların EBA Ders Sürelerini Yeterli Bulma Durumları

\begin{tabular}{lcc}
\hline & $f$ & $\%$ \\
\hline Evet yeterli & 100 & 46.51 \\
Hayır, yetersiz & 115 & 53.49 \\
Toplam & 215 & 100.00 \\
\hline
\end{tabular}

Tablo 10 incelendiğinde katılımcıların EBA ders sürelerini yeterli bulma durumlarına yer verildiği görülmektedir. Toplam 215 katılımcının 100’ü yani \%46.51 ders sürelerini yeterli bulduğunu ifade ederken katılımcıların \%53.49’u EBA ders süresini yeterli bulmadığını belirmiştir.

K32: Televizyon vb.uygulamalar ile Türkiye genelinde ögrencilerimizi ders noktasında etkin bir şekilde tutabilmek adına süre normal diyebiliriz. Tabi ki normal bir eğitim-öğretim süreci değil. Bunun yanında ben derslerimi uzaktan eğitim canl yayın ile sürdürmekteyim. Şu an için bu yüzden olabilecek belki de en iyisidir...

K106: Bu kadar kısa zamanda bu kadarı olabilirdi. Şu an için yeterli.

K189: Ekran başında kalma süresini düşününce yeterli.

K93: Çocukların dikkat ve algl seviyelerini göz önünde bulunduracak olursak ders anlatım süresi anlamında yeterli. Ancak etkinlik bazında yeterli bulmuyorum

K48: Kesinlikle bulmuyorum. 12 dakika ders 18 dakika teneffüs var. Bu kadar saçmalık olmaz.

K66: Hayır ders süreleri çok klsa.

Tablo11: Kat1lımcıların EBA Derslerini Tek Başına Yeterli Bulma Durumları

\begin{tabular}{lcc}
\hline & $f$ & $\%$ \\
\hline Evet yeterli & 50 & 23.26 \\
Hayir, yetersiz & 165 & 76.74 \\
Toplam & 215 & 100.00 \\
\hline
\end{tabular}

Tablo 11'e bakıldığında EBA derslerini tek başına yeterli bulan 50 katılımcının varlığı görülmektedir. Ancak toplam 215 katılımcının 165 tanesi yani \%76.74 gibi büyük bir çoğunluğu EBA derslerini tek başına yeterli bulmadıklarını ifade etmişılerdir.

K70: Asla yeterli değil, evet çocuklar uzaktan eğitimde kısıtlı süre odaklanabiliyorlar ama içerik yalnızca dersle kısıtlı kalmasa okuma saatleri de yapılsa ya da daha farklı eğlenceli içerikler sunulsa daha yararlı olacağını düşünüyorum. Çünkü bazı velilerim evde çalıştığını öne sürerek ögrencilerin kaliteli vakit geçiremedikleri ve yalnız kaldıklarını oyun türetemediklerini ve saldırgan tutumlar sergilediğini söylüyor.

K79: Öğrenciyle göz teması kurulamıyor ve her sinıfta ilerde geride olan ögrrenciler var bireysel farklılıklar göz ardı edilmek zorunda kalıyor. 
K151: Internetten EBA'ya erişim sağlayamayanlar için alıştırma, yazı yazma test çözme gibi kısıtlllıklar doğuyor. Bunları da biz ders kitaplarımızdan ödevlendirme ile telafi etmeye çalışıyoruz.

Tablo 12: Katılımcılar Tarafından EBA Derslerinin Okul Türüne Göre Tek Başına Yeterli Bulma Durumlar1

\begin{tabular}{llcc}
\hline & & $f$ & $\%$ \\
\hline \multirow{3}{*}{ Devlet okulu } & Evet yeterli & 45 & 22.96 \\
& Hayır, yeterli değil & 151 & 77.04 \\
& Toplam & 196 & 100 \\
\hline \multirow{3}{*}{ Özel okulu } & Evet uygun & 5 & 26.32 \\
& Hayır, yeterli değil & 14 & 73.68 \\
& Toplam & 19 & 100 \\
\hline
\end{tabular}

Tablo 12 incelendiğinde devlet okulunda görev yapan katılımcıların \%77.04 EBA derslerini tek başına yeterli bulmadığı, özel okulda görev yapan katılımcıların benzer şekilde \%73.68'nin EBA derslerinin yalnız başına yeterli olmadığını ifade ettiği görülmektedir.

K93 (Devlet Okulu):Tek başına yeterli bulmuyorum. Tabii ki uzaktan eğitim olduğu için anında dönüt verilemiyor ve sınıf ortamındaki gibi etkin katılım gerçekleştirdiğini düsünmüyorum. Çünkü ailelerin çoğunun sosyoekonomik düzeyi düşük ve eğitim durumlarl genellikle ya ilkokul mezunu ya da ilkokul mezunu bile değil. Bu anlamda çocuklarla çok ilgilenmiyorlar ve bu süreçte çocuklara çok yardımcı olamadıklarını düşünüyorum. Bu anlamda ailelere sürece daha aktif katılım sağlayabilecekleri bir ĕgitim verilebilir.

K156 (Devlet Okulu): Tek başına yeterli olduğunu düşünmüyorum. Çeşitlendirilmesi gerektiğini düşünüyorum. Destek anlatımlar, eğitici oyunlar, interaktif testler, çoklu değerlendirme yöntemlerinin olması gerektiğini düşünüyorum.

K39 (Özel Okul): Hayır yeterli bulmuyorum. Ögrencilerin konulart pekistirebileceği etkinlikler ve uygulamalar arttırllabilir ayrıca ögrenciler için eğitici içerikler arttırabilir.

K87 (Özel Okul) Klsmen. Seviye olarak biraz daha basit olduğunu düsünüyorum.

Tablo 13: Katılımcıların EBA Derslerini Okul Konumuna Göre Tek Başına Yeterli Bulma Durumlar1

\begin{tabular}{llcc}
\hline & & $f$ & $\%$ \\
\hline \multirow{3}{*}{ Şehir merkezi } & Evet uygun & 24 & 26.37 \\
& Hayır, uygun değil & 67 & 73.67 \\
& Toplam & 91 & 100 \\
\hline \multirow{3}{*}{ İlçe merkezi } & Evet uygun & 24 & 25.53 \\
& Hayır, uygun değil & 70 & 74.47 \\
& Toplam & 94 & 100 \\
\hline \multirow{3}{*}{ Köy merkezi } & Evet uygun & 5 & 16.67 \\
& Hayır, uygun değil & 25 & 83.33 \\
& Toplam & 30 & 100 \\
\hline
\end{tabular}

Tablo 13'de EBA derslerinin okul konumuna göre tek başına yeterliliğine bakıldığında Şehir merkezinden köy bölgesine gidildikçe uygun bulmayan katılımcı yüzdesinin artış gösterdiği görülmektedir. Şehir merkezinde görev yapan katılımcıların \%24 ü EBA'yı uygun bulurken İlçede görev yapanların 25.53'ü köyde görev yapan katılımcıların ise yalnızca \% 16.67'si EBA derslerini tek başına yeterli bulduğunu ifade etmiştir. 
K10 (Şehir Merkezi): Hayir yeterli değil. Karşılıklı etkileşim yok. İlkokul çocuğu etkileşim olmadan ders anlayamaz işleyemez.

K178 (İlçe Merkezi): Eba dersleri tek başına yeterli değil. Konu anlatımının dışında örnek çözümü yapılmalı, derslerde etkinlik örneği olmall, gerekli süre verilerek çocukların da aktif çözüm yapmasi gereklidir.

K36 (Köy Merkezi): Sadece anlatım olması orada örnekleri çözüyor olmaları her öğrenci için yeterli olmuyordur. Konu konu, öğrenci ögrenci değişiklik göstermekle beraber öğrenim tam anlamıyla sağlanamıyordur. Normal öğretim de bizler öğrencilere birçok etkinlik ve çalışma kâğıdı dağıtarak ödev vererek ögrenimi să̆layıp pekiştiriyoruz. Ancak EBA da bu pek mümkün değil. Bu nedenle çok üst seviyede bir öğretim sağlayacağını düşünmüyorum. Genel itibarıyla bir ögrretim sağlayabilir

Tablo 14: Katılımcıların Örencilerine Ek Ödev Ve Görevlendirme Verebilmek İçin Kullandıkları İletişim Yoları

\begin{tabular}{cc}
\hline En çok kullanılan & 1. Telefon görüşmesi \\
araçlar. & 2. WhastAap uygulaması \\
& 3. Eba internet sitesi ile ödevlendirme \\
4. Zoom uygulaması
\end{tabular}

Tablo 14'e bakıldığında katılımcıların ek ödev ve görevlendirme yapabilmek için en çok telefonla görüşme yöntemini tercih ettiği görülmektedir. Buna ek olarak WhatsApp uygulaması, EBA sitesini kullanma ve zoom programıla ek ödev ve görevlendirme yaptıklarını ifade etmişlerdir.

K191: Uzaktan eğitim başladĭ̆ süreden itibaren velilerime kaçının evinde internet ve bilgisayar olduğu sorusunu sordum. Aldığım yanıt oldukça yetersiz bir saylya denk geldiğinden velilerime televizyon üzerinden derslerin dinlenmesi gerektiğini söyledim. Ders bitiminden sonra konu ile ilgili özeti ve çözümlü soruları yazıp fotoğrafinı çektim whatsapp uygulaması üzerinden sınıf Veli grubuma gönderdim. Çocuklar böylece konu ile ilgili özeti günü gününe defterlerine geçirme firsatı buldular. Ardından hafta içi her akşam saat 8:30 da - bir ögrencimin annesi hemşire olduğundan onun ilgilenebilme saatini baz aldık- ögrencilerimi whatsapp üzerinden günün dersiyle ilgili kü̧̈ük bir sinava tabi tuttum. Ĕger öğrencilerim yeterli alt yapıya sahip olsaydı Kahoot!, Quizizz gibi uygulamalar üzerinden bu sinavları yapmak oldukça keyifli olabilirdi. Şimdilik en azından bunu gerçekleştiriyor olmak da güzel. Bunun dışında kitap okuma özet formu gönderdim. Her okudukları kitap için ayrı özet formu dolduruyorlar. Ayrıca her hafta sonu için evde yaratıcılıklarını sergileyebilecekleri ödevlendirmeler veriyorum. Dünya Tiyatrolar Günü için maske tasarımı ve geçtiğimiz hafta sonu için kendi oyununu kendin tasarla ve videosunu oyunun kurallarıyla birlikte anlatarak çekme ödevlendirmesi yapmıştım. Öğrencilerimi zorlamıyorum öncelikle güler yüz çok önemli çünkü oldukça zor günler geçiriyorlar.

Tablo 15: Katılımcıların Uzaktan Eğitim Sürecinde Öğrencilerine Ulaşabilme Durumları

\begin{tabular}{lcc}
\hline & $f$ & $\%$ \\
\hline Evet ulaşabiliyorum & 148 & 68.84 \\
Hayır, ulaşamıyorum & 67 & 31.16 \\
Toplam & 215 & 100.00 \\
\hline
\end{tabular}

Tablo 15'e bakıldığında 215 katılımcının 148'i yani \%68.84'ünün öğrencilere ulaşmada sorun yaşamadığını belirttiği görülmektedir. 67 katılımc1 yani tüm katılımcılarının \%31.16's1 öğrencilere ulaşmada sorun yaşadığı belirtmiştir. Bu sorunların başında sosyo-ekonomik nedenlerin geldiğine dair görüşler fazladır. 
K38: Maalesef veliler ilgisiz. Sosyo-ekonomik durumları da kötü. Akıllı telefon kullanan veli de az.

K133: Bazı ögrencilerin evlerinde sabit internet veya yüksek kotalı internet paketleri yok. Bu da bu ögrencilerle eğitim öğretim faaliyetleri sürdürmeyi zorlaştırtyor.

K94: Zorlanıyorum. Velilerimin birçoğunun akıllı telefonu yok. Ve çocuklarına karşı ilgisiz olduklarından dolayı iletişimde güçlük yaşıyorum.

K202: Zorlanıyorum. Öğrenci ailelerinin teknoloji kullanmada eksiklikler ve ailelerin eğitim seviyesindeki düşüklüğ̈̈...

Tablo 16: Katılımcıların Öğrencilerine Okul Türüne Göre Ulaşabilme Durumları

\begin{tabular}{llcc}
\hline & & $f$ & $\%$ \\
\hline \multirow{3}{*}{ Devlet okulu } & Evet ulaşabiliyorum & 131 & 66.84 \\
& Hayır, ulaşamıyorum & 65 & 33.16 \\
& Toplam & 196 & 100 \\
\hline \multirow{3}{*}{ Özel okulu } & Evet ulaşabiliyorum & 17 & 89.47 \\
& Hayır, ulaşamıyorum & 2 & 10.53 \\
& Toplam & 19 & 100 \\
\hline
\end{tabular}

Tablo 16 İncelendiğinde devlet okulunda görev yapan toplam 196 katılımcının 131'i öğrencilere ulaşmada zorluk yaşamadığını belirtmiş, 65 katılımcı yani devlet okullu katılımcılarının tamamının \%33.16'sı öğrencilere ulaşmada sorunlar yaşadığ 1 aktarmıştır. Özel okulda görev yapan katılımcıların \%89.47 gibi yüksek bir çoğunlu öğrencilere ulaşmada her hangi bir sorun yaşamadığını ifade etmiştir.

K96 (Devlet Okulu): Ulaşamadiğım var. İnterneti olmayan ya da okuma yazma bilmeyen çok velim var nu yüzden ödev yaptırımı konusunda zorluklar yaşıyorum

K100 (Devlet Okulu): Evet. Hiç interneti olmayan ve velilerine ulaşılamayan ögrenciler var.

K32 (Özel Okul): Hayır, zorluk yaşamıyorum.

Tablo 17: Katılımcıların Tarafından Okul Konumuna Göre Öğrencilerine Ulaşabilme Durumları

\begin{tabular}{cccc}
\hline & & $f$ & $\%$ \\
\hline \multirow{3}{*}{ Şehir merkezi } & Evet ulaşabiliyorum & 71 & 78.02 \\
& Hayır, ulaşamıyorum & 20 & 21.98 \\
& Toplam & 91 & 100 \\
\hline \multirow{3}{*}{ İlçe merkezi } & Evet ulaşabiliyorum & 67 & 71.28 \\
& Hayır, ulaşamıyorum & 27 & 28.72 \\
& Toplam & 94 & 100 \\
\hline \multirow{3}{*}{ Köy merkezi } & Evet ulaşabiliyorum & 10 & 33.33 \\
& Hayır, ulaşamıyorum & 20 & 67.67 \\
& Toplam & 30 & 100 \\
\hline
\end{tabular}

Tablo 17 da okulun bulunduğu konuma göre katılımcıların öğrencilere ulaşabilme durumlarına yer verilmiştir. Şehir merkezinde görev yapan katılımcıların \%78.02'sinin öğrencilere ulaştığ 1 , ilçe de görev yapan katılımcıların \%71.28'inin öğrencileriyle iletişim kurabildiği görülmektedir. Köy de görev yapan katılımciların ise yalnızca \%33.33’ü öğrencilerine ulaşabildiğini ifade etmiştir. Köyde görev yapan öğretmenlerin \%67.67'si öğrencilerine ulaşırken çeşitli sorunlarla karşılaştıklarını belirtmektedir. 
K36: Bir miktar zorlanıyorum. Köy okulu öğretmeni olmak bu konuda ögrenciye ulaşmamızı kisıtlayan bir durum. Çünkü köyde bu süreçte tarla çalışanları evde olmuyorlar pek görüşme sağlayamıyorum.

K79: Köy halkı gündüz mecburen tarlada olmak zorunda kaltyor. Durmadan çocukla ilgilenemiyorlar. Ödevleri yapma süreleri uzuyor.

Tablo18: Katılımcıların Öğrenci Velilerinin Mesleklerinin Uzaktan Eğitim Süreci Üzerindeki Etkisine Yönelik Görüşleri

\begin{tabular}{lcc}
\hline & $f$ & $\%$ \\
\hline Evet, veli mesleği süreci etkiliyor. & 178 & 82.79 \\
Hayır, veli mesleği süreci etkilemiyor & 37 & 17.21 \\
Toplam & 215 & 100.00 \\
\hline
\end{tabular}

Tablo 18 incelendiğinde veli mesleğinin uzaktan eğitim sürecini etkilediğine yönelik görüşlerin fazlalığı dikkat çekmektedir. 215 katılımcının 178'i yani tüm katılımcıların \%82.79'luk çoğunluğu velilerin yaptığı mesleğin uzaktan eğitim sürecini etkilediğini belirtmiştir. \%17.21'lik kısım ise sürecin veli mesleğinden etkilenmediğini belirtmiştir. Bu duruma ek olarak uzaktan eğitim sürecinde öğrenciyle en çok annelerin ilgilendiğine yönelik görüşler sıklık göstermektedir.

K32: Etkili bence... Ne yazık ki şu an zorluk yaşamama sebebim özel bir eğitim kurumunda yer almam. Çünkü veliler ile birlikte hiçbir şekilde iletişimimiz kopmadl. Bu ĕgitim- ögretim sürecinde en önemli dinamiklik bana kalırsa. Öğretmen- ögrenci - Veli ilişkisi. Bu noktada aslında imkânlar, şartlar, uygun koşullar demek daha da doğru olabilir... Bu hususta keşke tüm öğrenciler ile süreç aynı şekilde yaşaniyor olabilse.

K4: Etkiliyor. Velisi öğretmen olan ögrrencilerim bu süreçten olumsuz olarak daha az etkileniyor. Ya da ĕgitimle alakalı bir mesleği olanlar. sunabiliyor.

K48: Bence etkiliyor çünkü maddi durumu iyi olan veliler öğrenciye daha çok imkân

K105: Hayır. Çünkü öğrenci annelerinin birçoğu çalışmıyor. Bu nedenle özellikle anneler eğitim sürecinin takibini yapabiliyor.

Tablo 19: Katılımcıların Öğrenci Çalışma Ortamlarının Eğitime Uygunluğu Üzerine Görüşleri

\begin{tabular}{lcc}
\hline & $f$ & $\%$ \\
\hline Evet, uygun & 63 & 29.30 \\
Hayır, uygun değil & 152 & 70.70 \\
Toplam & 215 & 100.00 \\
\hline
\end{tabular}

Tablo 18'e bakıldığında 63 katılımcı öğrencilerinin çalışma ortamlarının eğitime uygunluk taşıdığını ifade ettiği görülmektedir. Ancak tüm katılımcıların \%70.70 gibi bir çoğunluğu öğrencilerin eğitime uygun bir ortama sahip olmadığını belirtmiştir. Uygun ortamın sağlanamaması konusundaki nedenler genellikle, teknolojik imkânların yetersiz olması, ev ortamının kalabalık olması, öğrencilerin kendilerine ait odalarının olmaması gibi sosyo-ekonomik nedenler olarak ifade edilmiştir.

K93: Uygun olduğunu düşünmüyorum. İnterneti, tableti, bilgisayarı, hatta akıllı telefonu olmayanlar var. Bunun dışında genellikle geniş aile ortamı var. Evler kalabalık. O kargaşa içinde çocukların derse adapte olması çok zor.

K48: Kesinlikle uygun olmadiğını düşünüyorum. Zaten tek odalı evleri var. Veya evde soba olduğu için tüm aile tek odada. Çocuk çalı̧̧amıyor.

K38: Uygun olmadiğın düşünüyorum. Yaşam koşulları, sosyo ekonomik durumları ve çok kardeşlik başta olan etkenlerdir. 
K32(Özel okul): Uzaktan eğitime uygun bir şekilde koşulları var. Bu yüzden onları çok şansll görüyorum...

Tablo 20: Süreçte Kullanılan Ek Kaynaklara Yönelik Görüşler

\begin{tabular}{lcc}
\hline & $f$ & $\%$ \\
\hline Süreç, ek kaynaklarla desteklenerek ilerliyor & 190 & 88.37 \\
Öğrenciler herhangi bir ek kaynağa sahip değil & 25 & 11.63 \\
Toplam & 215 & 100.00 \\
\hline
\end{tabular}

Tablo 20'ye bakıldığında uzaktan eğitim sürecinde ek kaynak kullanılma durumu görülmektedir. Tabloya göre katılımcıların \%88.37'si bu sürecin ek kaynaklarla desteklenerek yürütüldüğünü ifade etmiştir. Bu ek kaynaklar genel olarak hikâye kitapları, resimli çocuk kitapları, masallar ve test kitapları olarak belirtilmiştir. Öğrencilerin bir ek kaynağa sahip olmama durumlarında çeşitli iletişim araçlarıyla sürece destek olunduğu aktarılmıştır.

K93: Hikâye kitapları mevcut. Bunun dışında bazı resimli çocuk kitaplarını pdf formatında iletmiştim. Derslere kaynaklık edecek çalışma yaprakları ve alıştırmaları da ĕgitim portallarından bulup uygun olanları zaman zaman gönderiyorum. Tabii ki süreci destelemek adına bu kaynaklar önemli. Özellikle 1. Sinıf oldukları için okuma anlama açısından hikâye kitapları çok önemli.

K68: Köy Okulu olduğu için ve ne yazık ki ek kitap aldıramadiğımız için ders kitaplar dışında kendi kaynakları yok. Bu da ögrendikleri dersi tam anlamıyla pekiştirip başka yerlerden de yararlanamadıkları için öğrendikleri kalıcı olmayabilir. Onun dışında okuldan gönderdiğim hikâye kitapları var yanlarında okumaları için

K122: Kaynak kitapları mevcut. Uzaktan eğitim ile gördükleri ders ile alakalı konu tekrarı ve test çözümü yaptıkları için bu süreci olumlu olarak etkilemektedir.

K159: Hikâye kitabı, en önemli kaynă̆ımız, yolladı̆̆ım etkinlikler, görsel videolar, oyunlar süreci rahatlatıyor.

Tüm bu bulgulara ek olarak katılımcılar uzaktan eğitim sürecinde öğrenci ile iletişimin sınırlı olması, bazı öğrencilerin ek kaynak ve eğitime erişimde sorunlar yaşaması, uzaktan eğitimin bireysel farklılıklara hitap etmemesi, uzaktan eğitimde etkileşimin kısıtlı olması yönleriyle uzaktan eğitime eleştiriler getirmekte, korona virüs salgını ortamında hızlı bir şekilde eğitim faaliyetlerine yönelik çözümler geliştirilerek eğitime devam edilmesinin önemli olduğunu belirtmektedir.

\section{Sonuç, Tartışma ve Öneriler}

Araştırmanın bulgularından elde edilen sonuçlara göre korona virüs salgını nedeniyle başlatılan uzaktan eğitime erişim sağlamak için en çok televizyon kullanılmaktadır. Sınıf öğretmenleri uzaktan eğitim ders içeriklerini çoğunlukla kendi sınıf seviyelerine uygun bulurken, özel okulda görev yapan katılımcılara göre içerikler seviyeye göre yetersiz kalmaktadır. Ancak kentten kırsala doğru gidildikçe içerik seviyesinin uygunluğunun azaldığı düşüncesi yoğunluk kazanmıştır. Ders sürelerinin sınırlılığına yönelik görüşlerin fazlalığı dikkat çekmekte ve buna ilaveten ders içeriklerinin tek başına yeterli olmadığı görüşü savunulmaktadır. Öğrencilere salgın sürecinde en çok anneleri destek olmaktadır. Tüm bunlara ek olarak sosyo-ekonomik durumun uzaktan eğitime erişebilirliği ve bu eğitim sağlıklı bir şekilde sağlanabilmesine önemli etkileri olduğu araştırmanın önemli sonuçları arasındadır.

Uzaktan eğitimin amaçlarına ulaşabilmesi için her zaman ileri teknoloji kullanabilmek yeterli olmamaktadır (Tekinarslan, 2002). Bu duruma rağmen köy yerleşkeleri ve uzaktan eğitime erişmek için yeterli imkânlara sahip olmayan öğrenciler için televizyon gibi yaygın olarak kullanılan araçlarla eğitim sağlamak salgının eğitime olan etkisini en aza indirmek için güçlü bir yöntemdir. Araştırma sonuçlarına göre de uzaktan eğitim içeriklerine ulaşabilmek için en çok televizyondan yararlanıldığı görülmektedir. Ancak televizyon ya da diğer araçlarla etkileşimli bir 
ortam oluşturma açısından sorunlar yaşandığı katılımcılar tarafından eleştirilen noktalardır. Erturgut (2008) araştırmasının sonucunda etkili bir uzaktan eğitim için etkileşim sağlanabilmesinin önemine vurgu yapmaktadır. Bu çalışmanın sonuçları da uzaktan eğitimde önemli görülen noktalardan biri olarak etkileşimli ortamlar sağlanabilmesine dikkat çekmektedir.

Yamamoto ve Altun (2020) Covid-19 ve uzaktan eğitimi ele aldıkları çalışmalarının sonucunda gelecekte uzaktan eğitimin bir alternatif olmaktan çıkacağını ve eğitimin temel zemini haline geleceğini aktarmaktadırlar. Böyle bir durumda, bu araştırmanın sonuçlarından yola çıkılarak sosyo-ekonomik durumu düşük olan ailelerin çocukları için yeterli çalışmalar yapılmazsa eğitimde firsat eşitliğinden yararlanılmayacağı düşünülmektedir. Alpoga ve Oduncu Alpoga (2020) salgının sosyo-ekonomik sonuçlarını çeşitli alanlarda incelemeyi hedefleyen çalışmalarında, dijital eğitime geçilmesi durumunda kırsal kesimlerde bulunan okullar ve bu bölgede yaşayan ailelerin teknik araç gereç eksikliği ve yetersiz alt yapı sorunlarından olumsuz etkileneceğini, aynı zamanda kalabalık ailelerin eğitime devam etme konusunda sorunlar yaşayacağını öngörmüştür. $\mathrm{Bu}$ çalışmanın sonuçları Alpoga ve Oduncu Alpoga'nın (2020) öngörüleriyle yakınlık taşımaktadır. Uzaktan eğitimde dezavantajlı görülen bu gruplar için etkili çalışmalara ihtiyaç doğmaktadır.

Zhang, Wang, Yang ve Wang (2020) tarafından gerçekleştirilen salgın sürecinde Çin hükümetinin eğitim politikalarını değerlendiren çalışmada, süreçte yaşanacak olası zorluklar olarak öğretmenlerin deneyimsizliği, öğrencilerin yaşadıkları evlerdeki karmaşık ortam gibi sorunlara değinilmiş ve hükümetin çevrimiçi öğrenim güçlüğü olan öğrencilere destek sağlamasını gerektiğini belirtilmiştir. Özer (2020) salgın sürecinde Milli Eğitim Bakanlığının politikalarını derleyen çalışmasında, bakanlığın süreç içerisinde öğrencilerin akademik, sosyal ve psikolojik becerilerini desteklemeye yönelik önemli adımlar attığını belirtirken, aynı zamanda tüm öğrencilerin uzaktan eğitime ve diğer fırsatlara erişim sağlamasının eğitim yetkililerince önemsendiğini aktarmaktadır. Tüm bu çabalara ek olarak kırsal kesimlerde ya da şehir merkezinde bulunmasına rağmen çeşitli imkânsızlıklarla eğitim ve diğer firsatlardan yararlanmakta zorluk çeken öğrencilere odaklanılmalıdır. Bu süreçte öğretmenlerden yardım alınarak eğitime erişmede sorunlar yaşayan öğrenciler belirlenerek gerekli ihtiyaçlarının giderilmesine yönelik adımlar atılmalıdır.

Araştırmanın sonuçlarına göre merkezden uzaklaşıldıkça uzaktan eğitime devam eden öğrencilerin takibinin zorlaştığı görülmektedir. $\mathrm{Bu}$ durumun sosyo-ekonomik seviyenin azalmasıyla ilişkili olduğu aşikârdır. Çiftçi ve Çağlar (2014) sosyo-ekonomik durumun öğrenci başarısına etkisini inceleyen çalışmalarında, sosyo-ekonomik durumun başarıya olan olumsuz etkilerini azaltmak ve öğrencilerin sosyal ve akademik başarılarının sürekli takip edebilirliğini sağlamak adına okul yöneticileri, öğretmenler ve velilerin irtibat halinde olmaya teşvik edilmesi gerektiğini aktarmaktadır. Bu araştırmanın sonuçlarına bakıldığında uzaktan eğitimde öğrenci takibi için en çok telefonla iletişim gerçekleştirilebildiği ortaya çıkmıştır.

Salgın sürecini ela alan Saavedra (2020) salgının eğitime olan etkilerini yoksul çocukların daha fazla hissedeceğini belirtmekte, yaşanacak öğrenme kayıplarına ve okuldan ayrılma ihtimallerine değinmektedir, aynı zamanda dezavantajlı çocukların çalışma masası, kitap, internet altyapısı gibi teknik ya da eğitimsel faaliyetleri sürdürmek için gerekli olan araç gereçlere, ilgili ve öğrenciyi destekleyici ebeveynlere sahip olmadığından bahsetmektedir. Bu araştırma sonuçlarına göre de uzaktan eğitime erişimde ve sürdürülebilirliğinde öğrencinin öğrenimine devam ettiğgi okul türü ve konumu gibi değişkenlerin önemli etkilerinin olduğu görülmektedir. Öğrencinin çalışma ortamı, aile fertlerinin meslekleri, kardeş sayıları, yaşadıkları coğrafi bölge ve ailenin öğrenciye sunduğu imkânlar süreci etkilemektedir. Sosyo-ekonomik durumun akademik başarıyı benzer şekilde etkilediği sonucunu aktaran çalışmalar da vardır (Arslanargun, Bozkurt ve Sarığlu, 2016; Çiftçi ve Çağlar, 2014; Gelbal, 2008; Kazu, 2018; Kurt ve Taş, 2019). Tüm bunlara ek olarak uzaktan eğitim sürecinde öğrenciye en çok annelerin destek olduğu sonucuna ulaşılmıştır. İlkokul kademesinde yer alan öğrencilerin okur-yazarlığa ulaşabilmesi ve temel becerilerin kazanabilmesi 
açısından annenin sağlayabileceği destek önemlidir. Kurt ve Taş (2019) yaptıkları çalışmalarında sosyo-ekonomik düzeyi daha yüksek olan ebeveynlerin çocuğun eğitimini daha fazla desteklediği sonucunu ortaya koymuştur.

Crowford ve diğerleri (2020) 20 ülkenin Covid-19 sürecinde yüksek öğretim düzeyinde çevrimiçi eğitimlerini inceleyen çalışmalarında bir gecede çevrimiçi eğitime geçilmesinin güçlügünü vurgularken, yaşanacak zorluklarda öğrenci ve ailenin imkânsızlıklarından kaynaklanan sorunların yanı sıra akademisyenlerinde çevrimiçi eğitime yönelik bilgilerinin önemli olduğuna değinmektedir. Yüksek öğretim seviyesinde yaşanabilecek bu sıkıntılar tüm öğrenim seviyeleri için geçerlidir. Özellikle sınıf öğretmenleri ve ilkokul öğrencileri eğitimin en temel unsurları oldukları için yeterli imkânlarla buluşturulmalıdır.

Uzaktan eğitimi daha faydalı ilerletmek ve çocuğun akademik hayatının yanında sosyal hayatını da desteklemek adına ilkokul kademesine yönelik hazırlanan içeriklere masal anlatımları, parmak oyunları ve çocuk şarkıları eklenerek tüm ilkokul kademesinin ders kazanımları haricinde eğlence kuşağı oluşturularak destek olunabilir. Öğretmenler ve okul yöneticileri tarafindan belirlenen uzaktan erişime imkânı olmayan öğrencilere araç gereç desteği sağlanabilir. Aileler için içerikler hazırlanarak öğrenci eğitimine nasıl destek olunacağı hakkında bilgi verilebilir.

\section{Araştırmanın Sınırılııkları ve Gelecek Araştırmalara Öneriler}

Araştırmanın güvenirliğini artırmak için katılımcılara araştırma süreci ve amacı hakkında bilgi verilmiştir. Araştırmaya katılım tamamiyle gönüllük esasıyla gerçekletirilmiştir. Araştırmada kullanılacak anket formu geliştirilme sürecinde uzman görüşlerine başvurulmuş ve bu görüşler doğrultusunda anket formu oluşturulmuştur. Bunlara ilaveten katılımcıların öğrenci çalışma ortamların uzaktan eğitime uygunluğu ve süreç içerisinde ek kaynak kullanma durumlarına yönelik görüşlerinin okul konumuna göre değişkenlik gösterme durumların incelenmemiştir. Gelecek çalışmalarda bu değişkenlik durumu incelenebilir.

\section{Kaynakça}

Adıyaman, Z. (2002). Uzaktan eğitim yoluyla yabancı dil öğretimi. The Turkish Online Journal of Educational Technology, 1 (1), 92-97.

Al, U., ve Madran, R. O. (2004). Web tabanlı uzaktan eğitim sistemleri: Sahip olması gereken özellikler ve standartlar. Bilgi Dünyast, 5(2), 259-271.

Alpoga, H., ve Oduncu Alpoga, D. (2020). Koronavirüs salgınının sosyoekonomik sonuçları. IBAD Sosyal Bilimler Dergisi. (8), 99-144. https://doi.org/10.21733/ibad.716444

Astone, N. M., ve McLanahan, S. S. (1991). Family Structure, Parental Practices and High School Completion. American Sociological Review, 56(3), 318-330.

Ateş, A., ve Altun, E. (2008). Bilgisayar öğretmeni adaylarının uzaktan eğitime yönelik tutumlarının çeşitli değişkenler açısından incelenmesi. Gazi Eğitim Fakültesi Dergisi, $28(3), 125-145$.

Aydemir, M., Küçük, S., ve Karaman, S. (2012). Uzaktan eğitimde tablet bilgisayar kullanımına yönelik öğrenci görüşlerinin incelenmesi. Ĕgitim ve Öğretim Araştırmaları Dergisi, 1(4), 153-159.

Baeck, U. K. (2010). Parental involvement practices in formalized home-school cooperation. Scandinavian Journal of Educational Research, 54(6), 549-563.

Baker, D. P., Goesling, B., ve Letendre, G. K. (2002). Socioeconomic status, school quality, and national economic development: A cross-aational analysis of the "Heyneman- Loxley 
Effect" on mathematics and science achievement, Comparative Education Review, 46 (3), 291-312.

Baldwin, R and B Weder di Mauro (2020), Economics in the Time of COVID-19, a VoxEU.org eBook, CEPR Press.

Bayburtlu, Y.S. (2020). Covid-19 pandemi dönemi uzaktan eğitim sürecinde öğretmen görüşlerine göre Türkçe eğitimi. Turkish Studies, 15(4), 131-151. https://dx.doi.org/10.7827/TurkishStudies.44460

Birişçi, S. (2013). Video konferans tabanlı uzaktan eğitime ilişkin öğrenci tutumları ve görüşleri. Journal of Instructional Technologies \& Teacher Education, 1(2), 24-40.

Bozkurt, A. (2017). Türkiye'de uzaktan eğitimin dünü, bugünü ve yarını. AUAd, 3(2), 85-124.

Chiu, M. M., ve Khoo, L. (2005). Effects of resources, 1nequality, and privilege bias on achievement: Country, school, and student level analyses, American Educational Research Journal, 42(4), 575-603.

Chiu, M. M., ve Xihua, Z. (2008). Family and motivation effects on mathematics achievement: Analyses of students in 41 countries, Learning and Instruction, 18, 321-336.

Crowford, J., Henderson, B., K., Rudolpch, J., Malkawi, B., Glowatz, M., Burton, R., Magni, P., Lam, S. (2020). COVID-19: 20 countries' higher education intra-period digital pedagogy responses. Journal of Applied Learning \& Teaching, 3 (1), 1-20. https://doi.org/10.37074/jalt.2020.3.1.7

Çağıltay, K. (2002). “Uzaktan eğitim: Başarıya giden yol teknolojide mi yoksa pedagojide mi?”, [Çevrimiçi] Elektronik adres: http://www.teknoturk.org/docking/yazilar/tt000037- yazi.htm [07.04.2002]

Çiftçi, C., ve Çağlar, A. (2014). Ailelerin sosyo-ekonomik özelliklerinin öğrenci başarısı üzerindeki etkisi: Fakirlik kader midir? International Journal of Human Sciences, 11(2), 155-175. https://doi.org/10.14687/ijhs.v11i2.2914

Demir, E. (2014). Uzaktan eğitime gelen bir bakış. Dumlupınar Üniversitesi Sosyal Bilimler Dergisi, (39), 203-212.

Demir, İ. (2020). Kovid-19 salgının seyri ve Türkiye ekonomisi. Uluslararası İlişkiler ve Stratejik Araştırmalar (ULISA) Enstitüsü, 1, 7-16.

Duban, N., Şen, F. G. (2020). Sınıf öğretmeni adaylarının COVID-19 pandemi sürecine ilişkin görüşleri. Turkish $\quad$ Studies, $\quad$ 15(4), 357-376. https://dx.doi.org/10.7827/TurkishStudies.43653

EBA. (2017). EBA hakkında. 13.03.2017 tarihinde http://www.eba.gov.tr/hakkimizda.

Ekici, G. (2003). Uzaktan eğitim ortamlarının seçiminde öğrencilerin öğrenme sitillerinin önemi. Hacettepe Üniversitesi Ĕ̈itim Fakültesi Dergisi, (24), 48-55.

Erturgut, R. (2008). İnternet temelli uzaktan eğitimin örgütsel, sosyal pedagojik ve teknolojik bileşenleri. Bilim Teknolojileri Dergisi, 1(2), 79-85.

Gelbal, S. (2008). Sekizinci sınıf öğrencilerinin sosyoekonomik özelliklerinin Türkçe başarısı üzerinde etkisi. Ĕgitim ve Bilim, 33(150), 1-13.

Glesne, C. (2015). Becoming Qualitative Researchers: An Introduction (5.bs.). Pearson Education.

He, F., Deng, Y., ve Li, W. (2020) Corona virus disease 2019 (COVID-19): What we know? J Med Virol, 1-7. https://doi.org/10.1002/jmv.25766 
Heyns, B., ve Catsambis, S. (1986). Mother's employment and children's achievement: A critique. Sociology of Education, 59(3), 140-151.

Karahan, E. \& Bozan, M. A. \& Akçay, A. O. (2020). Sınıf öğretmenliği lisans öğrencilerinin pandemi sürecindeki çevrim içi öğrenme deneyimlerinin incelenmesi, Turkish Studies, 15(4), 201-214. https://dx.doi.org/10.7827/TurkishStudies.44348

Kazu, İ. Y. (2019). Sosyo-ekonomik açıdan dezavantajlı kişilerin eğitimleri sırasında karşılaştıkları sorunlar. Dicle Üniversitesi Ziya Gökalp Eğitim Fakültesi Dergisi, 38-47. http://dx.doi.org/10.14582/DUZGEF.1912

Kılıç, Y., ve Haşıloğlu, M. A. (2007). Sosyoekonomik durumun öğrenci başarısına etkisi (7. sınıf Türkçe ve fen bilimleri dersleri örneklemi). YYÜ Ĕgitim Fakültesi Dergisi (YYU Journal Of EducationFaculty), 14(1), 1025-1049. doi: http://dx.doi.org/10.23891/efdyyu.2017.38

Kırık, A. M. (2014). Uzaktan eğitimin tarihsel gelişimi ve Türkiye'deki durumu. Marmara İletişim Dergisi, (21), 73-94. https://doi.org/10.17829/midr.20142110299

Kurt, U., ve Taş, Y. (2019). Ebeveynlerin sosyoekonomik düzeyleri ile çocukların okul hayatına katılımları arasındaki ilişki. Kuramsal Eğitimbilim Dergisi, 12(3), 978-991. http://dx.doi.org/10.30831/akukeg.470256

Lee, Jong-Wha ve Barro, R. J. (1997). Schooling Quality in A Cross Section of Countries, NBER Working Papers 6198, National Bureau of Economic Research, Inc.

Lee, J. S., ve Bowen, N. K. (2006). Parent involvement, cultural capital, and the achievement gap among elementary school children. American Educational Research Journal, 43, 193-218.

Lueptow, L. B. (1975). Parental status and influence and the achievement orientations of high school seniors. Sociology of Education, 48(Winter), 91-110.

Lu, R., Zhao, X., Li, J., Niu P, Yang, B., Wu, H., ve diğerleri. (2020). Genomic characterisation and epidemiology of 2019 novel coronavirus: implications for virus origins and receptor binding. Lancet, 395,565-574. https://doi.org/10.1016/S0140-6736(20)30251-8

Miles, M. B. ve Huberman, A. M. (1994). Qualitative data analysis: An expanded sourcebook. Thousand Oaks, Sage

Milli Eğitim Bakanlığı MEB. (2020). Uzaktan eğitim 30 Nisan'a kadar devam edecek.https://www.aa.com.tr/tr/egitim/milli-egitim-bakani-selcuk-uzaktan-egitim-30 nisana-kadar-devam-edecek/1779414 erişildi.

Millî Eğitim Bakanlığı (MEB). (2015). Eğitimde FATïH Projesi web sayfası. Erişim http://FATİHprojesi.meb.gov.tr/tr/index.php

Milne, A. M., Myers, D.E., Rosenthal, A. S., ve Ginsburg, A. (1986). Single parents, working mothers, and the educational achievement of school children. Sociology of Education, 59(3), 125-139.

Newby,T.J., Stepich, D.A., Lehman, J.D., ve Russell, J.D. (2006). Educational Technology for Teaching and Learning. Upper Saddle River, Pearson Merrill Prentice Hall.

Odabaş, H. (2003). İnternet tabanlı uzaktan eğitim ve bilgi ve belge yönetimi bölümleri. Türk Kütüphaneciliği, 17(1), 22-36.

OECD (2020). Evaluating the initial impactofCOVID-19 containment measures on economic activity, https://read.oecdilibrary.org/view/?ref=126_126496evgsi2gmqj\&title=Evaluating_the_initi al_impactof_COVID 19_containment_measures_on_economic_activity erişildi. 
OECD (2013). PISA 2012 results in focus, What 15-year-olds know and what they can do with what they know.

Oran, M. K., ve Karadeniz, Ş. (2007). Internet tabanl uzaktan eğitimde mobil öğrenmenin rolü. Akademik Bilişim'07 - IX. Akademik Bilişim Konferansı Bildirileri 31 Ocak - 2 Şubat 2007 Dumlupınar Üniversitesi.

Orhan, F., ve Akkoyunlu, B. (1999). Uzaktan eğitim yaklaşımında temel eğitim 1. kademe öğretmenleri'nin video destekli hizmet içi eğitimi. Hacettepe Üniversitesi Ĕgitim Fakültesi Dergisi, 16(17), 134-141.

Özer, M. (2020). Türkiye'de COVID-19 salgını sürecinde Milli Eğitim Bakanlığı tarafından atılan politika adımları. Kastamonu Education Journal, 28(3), 1124-1129. https://doi.org/10.24106/kefdergi.722280

Özkul, A.E., ve Girginer, N. (2001). Uzaktan eğitim teknoloji ve etkinlik. Invited paper for the "International Educational Technology Conference and Fair 2001" Sakarya University.

Pala, F, Arslan, H, ve Özdinç, F. (2017). Eğitim Bilişim Ağı web sitesinin otantik görevler ve göz izleme ile kullanılabilirliğinin incelenmesi. Ihlara Eğitim Araştırmaları Dergisi, 2(1), 24 38 .

Patton, M. (2002). Qualitative Research and Evaluation Methods (3.bs.). Sage Publications: Thousand Oaks.

Saavedra, J. (2020). Educational challenges and opportunities of the Coronavirus (COVID-19) pandemic. World Bank Blogs. https://blogs.worldbank.org/education/educationalchallenges-and-opportunities-covid-19-pandemic adresinden 18.05. 2020 tarihinde erişildi.

Sirem, Ö., Baş, Ö. (2020). Okuma güçlüğü olan ilkokul öğrencilerinin Covid-19 sürecinde uzaktan eğitim deneyimleri. Turkish Studies, 15(4), 993-1009. https://dx.doi.org/10.7827/TurkishStudies.43346

Sui-Chu, E. H., ve Willms, J.D. (1996). Effects of parental involvement on eight-grade achievement. Sociology of Education, 69(2), 126-141.

Teachman, J. D. (1987). Family background, educational resources, and educational attainment, American Sociological Review, 52(4), 548-557.

TEDMEM (2020). COVID-19 sürecinde öğretmenler, https://tedmem.org/covid-19/covid-19salgini-surecinde-ogretmenler\#note-3264-1

Tekinarslan, E. (2002). "Distance education: Technologies, 1ssues and considerations", Abant İzet Baysal Üniversitesi Eğitim Fakültesi Dergisi, 2(3), 65-73.

UNESCO. (2020). COVID-19 educational disruption and response. https://en.unesco.org/covid19/educationresponse

USDLA. (2004). United States Distance Learning Association: Definition of distance learning. 16 Temmuz 2004 tarihinde http://www.usdla.org

Üstün, Ç, ve Özçiftçi, S. (2020). COVID-19 pandemisinin sosyal yaşam ve etik düzlem üzerine etkileri: Bir değerlendirme çalışması. Anadolu Kliniği Tıp Bilimleri Dergisi 25(1), 142-153. https://doi.org/10.21673/anadoluklin.721864

Vellymalay, S. K. N. (2012). The impact of parent's socioeconomic status on parental involvement at home: A case study on high achievement Indian students of a Tamil school in Malaysia. International Journal of Academic Research in Business and Social Sciences, 2(8), 11-24. 
Viner, R., Russell, S.J, Croker, H., Packer, J., Ward, J., Stansfield, C., ...Booy, R. (2020). School clouse and management practices during coronovirus outbreaks including COVID-19: A rapid systematic review. The Lancet Child \& Adolescent Health, 4, 397-404.

Yalman, M. (2013). Eğitim fakültesi öğrencilerinin bilgisayar destekli uzaktan eğitim sistemi (MOODLE) memnuniyet düzeyleri. Turkish Studies, 8(8), 1395-1406.

Yamamoto, G., T., ve Altun, D. (2020). Coronavirüs ve çevrimiçi (Online) eğitimin önlenemeyen yükseliși. Üniversite Araştırmalarl 25-34. https://doi.org/10.21673/anadoluklin.721864

Yavuz, S., Odobaş, M., ve Özdemir, A. (2016). Öğrencilerin sosyoekonomik düzeylerinin TEOG matematik başarısına etkisi. Ĕgitimde ve Psikolojide Ölçme ve Değerlendirme Dergisi, 7(1), 85-95. https://doi.org/10.21031/epod.86531

Yolsal, H. (2016). Öğrencilerin sosyo-ekonomik ve kültürel statülerinin PISA 2012 başarıları üzerindeki etkisinin incelenmesi. Social Sciences Research Journal, 5(3), 7-27.

Zhang, W., Wang, Y., Yang, L., ve Wang, C. (2020). Suspending clases without stopping learning: China's education emergency managament policy in the COVID-19 outbreak. Journal of Risk and Financial Management, 13(3), 55. https://doi.org/10.3390/jrfm13030055

Zhong, R. (2020). The Coronavirus Exposes Education's Digital Divide. nytimes.com: https://www.nytimes.com/2020/03/17/technology/china-schools-coronavirus.html.

3.4\% Mortality Rate estimate by the World Health Organization (WHO) as of March 32020. https://www.worldometers.info/coronavirus/coronavirus-death-rate/\#correct

\section{Ekler}

Ek 1: Veri Toplama Sürecinde Kullanılan Anket Formu Soruları.

Mezun olduğunuz üniversite / bölüm nedir?

Sınıf öğretmenliğinde mesleki kıdeminiz nedir?

Şu anda kaçıncı sınıfi okutuyorsunuz?

Görev yaptı̆̆ınız okul nerede?

Hangi okul türünde görev yapmaktasınız?

Kaç öğrenciniz var ve öğrencilerinizin kaçı EBA uygulamasına erişiyor?

Öğrencileriniz EBA uygulamasına nasıl erişim sağlıyor?

EBA uygulaması içeriklerinin sizin öğrencilerinizin seviyelerine uygun olduğunu düşünüyor musunuz?

EBA uygulamasının ders süresini yeterli buluyor musunuz?

EBA derslerinin öğretim için tek başına yeterli olduğunu düşünüyor musunuz? Değilse eksiklikleri nelerdir?

Öğrencilerinize ek ödev ve görevlendirme sağlamak için hangi uygulama ve iletişim kanallarını (Telefon,

Sosyal medya, vb.) kullanıyorsunuz?

Uzaktan eğitim döneminde öğrencilerinize ulaşmakta zorlanıyor musunuz? Zorlanıyorsanız bu zorluklar nelerdir?

Öğrenci velilerinin meslekleri sizce uzaktan eğitim sürecini etkiliyor mu?

Öğrencilerinize uzaktan eğitim sürecinde aile içinde kim veya kimler yardımcı oluyor?

Öğrencilerinizin genelinin çalışma ortamının uzaktan eğitime uygunluğu hakkında görüşleriniz nelerdir?

Öğrencilerinizin ders kitapları dışında faydalanacağı ek kaynaklar (Hikaye kitabı gibi) var mı? Bu kaynaklar uzaktan eğitim sürecini nasıl etkiler?

Uzaktan eğitim sürecinin olumlu ve olumsuz yönleri sizce neler olabilir?

Varsa sizin eklemek istedikleriniz. 